\title{
R E L I G I O N A N D A M E R I A N C U L T U R E

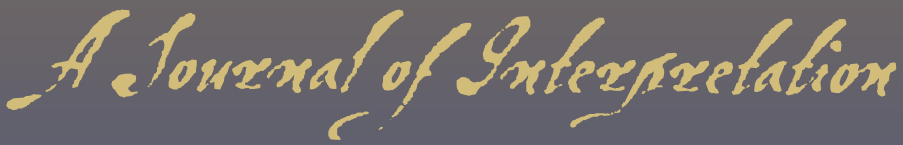

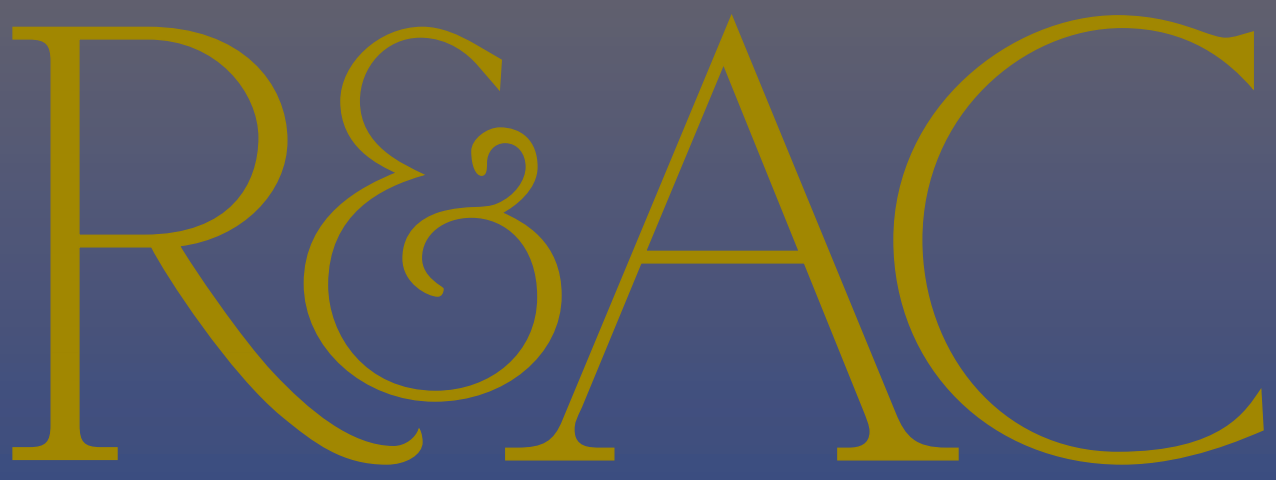

Published for

The Genter for the Study of Religion and American Culture by Cambridge University Press 


\section{Statement of Purpose}

Religion and American Culture: A Journal of Interpretation explores the interplay between religion and other spheres of American culture. The journal embraces a diversity of methodological approaches and theoretical perspectives. Although concentrated on specific topics, articles illuminate larger patterns, implications, or contexts of American life. Religion and American Culture is, thus, devoted to promoting the ongoing scholarly discussion of the nature, terms, and dynamics of religion in America.

Religion and American Culture (ISSN 1052-1151, e-ISSN 1533-8568) is published three times a year (January, May, and September) by Cambridge University Press (One Liberty Plaza, 20th Floor, New York, NY 10006) for The Center for the Study of Religion and American Culture. POSTMASTER: Send address changes to Religion and American Culture, Cambridge University Press, One Liberty Plaza, 20th Floor, New York, NY 10006, USA.

See https://www.cambridge.org/core/journals/religion-and-americanculture/subscribe for single issue and subscription orders and claims information. Domestic claims for nonreceipt of issues should be made within 90 days of the mail date; overseas claims within 180 days. Cambridge University Press does not begin accepting claims for an issue until thirty (30) days after the mail date. Out-of-print issues and volumes are available from Periodicals Service Company, 11 Main Street, Germantown, NY 125265635, phone: 518-537-4700, fax: 518-537-5899, http:/ / www.periodicals.com.

Inquiries about advertising can be sent to USAdSales@cambridge.org. For complete abstracting and indexing coverage for the journal, please visit https://www.cambridge.org/core/journals/religion-and-american-culture. For submission information, please go to: https://religionamericanculture. submittable.com/submit. All other inquiries can be directed to journals@ cambridge.org.

Copying and permissions notice: Authorization to copy article content beyond fair use (as specified in Sections 107 and 108 of the U.S. Copyright Law) for internal or personal use, or the internal or personal use of specific clients, is granted by The Regents of the University of California for libraries and other users, provided that they are registered with and pay the specified fee through the Copyright Clearance Center (CCC), www.copyright.com. To reach the CCC's Customer Service Department, phone 978-750-8400 or write to info@copyright.com. For permission to distribute electronically, republish, resell, or repurpose material, and to purchase article offprints, use the CCC's Rightslink service, available at http:/ / rac.ucpress.edu. Submit all other permissions and licensing inquiries through Cambridge University Press's Rights and Permissions's web page, http://www.cambridge.org/rights / permissions/permission.htm or via email permissionssalesUK@cambridge.org.

Printed by The Sheridan Press on Forest Stewardship Council ${ }^{\circledR}$-certified paper.

(C) 2019 The Center for the Study of Religion and American Culture. All rights reserved. 


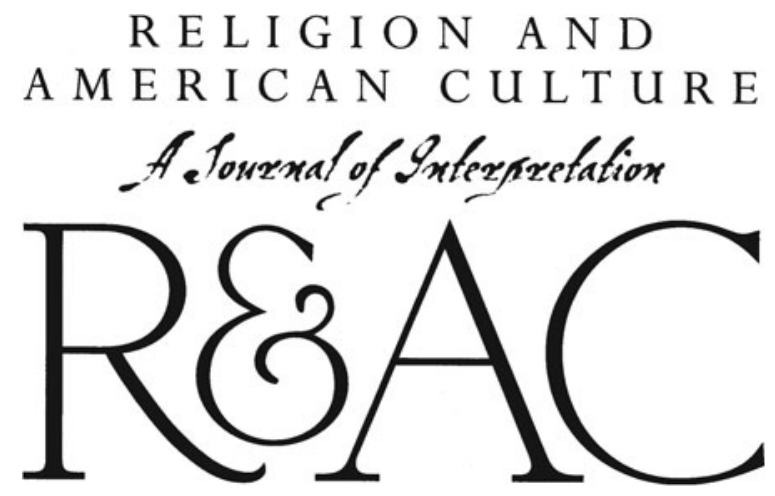

Winter 2019 Volume 29 Number 1

\section{CONTENTS}

1 Forum: The Religious Situation, 1968 (Part 1)

with contributions by Kathleen Holscher

Jonathan Ebel

Jana Riess

Joseph L. Tucker Edmonds

Angie Heo

Ari Y. Kelman

36 American Catholics and "The Use and Abuse of Reading," 1865-1873

Erin Bartram

65 "Development of Body, Mind, and Soul:" Paramahansa Yogananda's Marketing of Yoga-Based Religion Dave J. Neumann

102 The Parliament of Empire: Charles Bonney's American Vision Lucia Hulsether 


\section{EDITORS}

Julie Byrne

Hofstra University

Thomas Davis

Indiana University-Purdue University Indianapolis

Tracy Fessenden

Arizona State University

Philip Goff

Indiana University-Purdue University Indianapolis

Laura Levitt

Temple University

Matthew Avery Sutton

Washington State University

Peter J. Thuesen

Indiana University-Purdue University Indianapolis

Judith Weisenfeld

Princeton University

\section{ASSISTANT}

Nathaniel Wynne

\section{BOARD OF EDITORS}

Conrad Cherry, Indiana University-Purdue University Indianapolis (emeritus)

Charles L. Cohen, University of Wisconsin-Madison

Dennis C. Dickerson, Vanderbilt University

Kathleen Flake, University of Virginia

Terryl L. Givens, University of Richmond

R. Marie Griffith, Washington University in St. Louis

Paula Kane, University of Pittsburgh

Laurie F. Maffly-Kipp, Washington University in St. Louis

Timothy Matovina, University of Notre Dame

Michael D. McNally, Carleton College

David Morgan, Duke University

Deborah Dash Moore, University of Michigan

Ronald L. Numbers, University of Wisconsin-Madison

Laura R. Olson, Clemson University

Robert A. Orsi, Northwestern University

Anne C. Rose, The Pennsylvania State University

Leigh E. Schmidt, Washington University in St. Louis

Jan Shipps, Indiana University-Purdue University Indianapolis (emeritus)

Grant Wacker, Duke University

Rhys H. Williams, Loyola University Chicago 